\title{
Biological sulphate reduction with primary sewage sludge in an upflow anaerobic sludge bed (UASB) reactor - Part 3: Performance at $20^{\circ} \mathrm{C}$ and $35^{\circ} \mathrm{C}$
}

\author{
J Poinapen, GA Ekama* and MC Wentzel \\ Water Research Group, Dept. of Civil Engineering, University of Cape Town, Rondebosch 7701, South Africa
}

\begin{abstract}
The performance of 2 biological sulphate reduction (BSR) upflow anaerobic sludge bed (UASB) reactors fed primary sewage sludge (PSS) and sulphate, one at $20^{\circ} \mathrm{C}(\mathrm{R} 2)$ and one at $35^{\circ} \mathrm{C}(\mathrm{R} 1)$ is described. To maintain the effluent sulphate concentration below $250 \mathrm{mgSO}_{4}^{2-/ \ell}$, the hydraulic retention time (HRT) and bed solids retention time (SRT or sludge age) both needed to be longer and the feed primary sewage sludge (PSS) COD to $\mathrm{SO}_{4}^{2-}$ ratio higher at $20^{\circ} \mathrm{C}$ than at $35^{\circ} \mathrm{C}$, viz. 20.4 to $21.0 \mathrm{~h}, 24 \mathrm{~d}$ and $1.75 \mathrm{gCOD} / \mathrm{gSO}_{4}{ }^{2-}$ at $20^{\circ} \mathrm{C}$ and 16.4 to $17.0 \mathrm{~h}, 21 \mathrm{~d}$ and $1.75 \mathrm{gCOD} / \mathrm{gSO}_{4}{ }^{2-}$ at $35^{\circ} \mathrm{C}$ respectively. The longer HRT, SRT and higher feed PSS COD/ $\mathrm{SO}_{4}{ }^{2-}$ ratio is a consequence of a slower PSS hydrolysis/acidogenesis rate at $20^{\circ} \mathrm{C}$ resulting in a lower biodegradable particulate organics conversion to volatile fatty acids (VFA). Solid liquid separation in both systems was good yielding average particulate and soluble organic COD concentrations of $(150$ and $100 \mathrm{mgCOD} / \ell$ for $\mathrm{R} 1 ; 138$ and $96 \mathrm{mgCOD} / \ell$ for R2). The sulphate reduction was $>90 \%$ in both systems. The UASB reactor R1 (at $35^{\circ} \mathrm{C}$ ) was also operated at an increased influent sulphate concentration $\left(1800 \mathrm{mgSO}_{4}{ }^{2-/ \ell}\right)$ to investigate the inhibition effect by un-dissociated hydrogen sulphide generated from the reduction of this high sulphate concentration. It was found that a high sulphate reduction ( $\sim 92 \%)$ was maintained even at the relatively low HRT of $18.5 \mathrm{~h}$. The COD and S mass balances above $95 \%$ were achieved over both systems indicating that the performance data obtained from them is reliable for developing and calibrating mathematical models.
\end{abstract}

Keywords: biological sulphate reduction, hydrolysis, hydraulic retention time, UASB reactor

\section{Nomenclature}

Alk $\mathrm{H}_{2} \mathrm{~S}$ alkalinity with respect to the $\mathrm{H}_{2} \mathrm{~S}$ reference species excluding the water species

AMD acid mine drainage

BPO biodegradable particulate organics

BRT bed retention time

BSR biological sulphate reduction

COD chemical oxygen demand

FBR fluidised bed reactor

$f_{c v} \quad$ COD to VSS ratio

$\mathrm{f}_{n}^{\mathrm{cv}} \quad$ orgN/VSS ratio

$\mathrm{f}_{\text {PS'up }}^{\text {n }} \quad$ influent and biodegradable particulate COD fraction of primary sludge

FRBCOD fermentable readily biodegradable COD

FSA free and saline ammonia $\begin{array}{ll}\mathrm{H}_{2} \mathrm{CO}_{3} * \mathrm{Alk} & \begin{array}{l}\text { alkalinity with respect to the } \mathrm{H}_{2} \mathrm{CO}_{3} \text { reference } \\ \text { species including the water species }\end{array}\end{array}$

HAc acetic acid

HRT hydraulic retention time

$\mathrm{K}_{\mathrm{I}} \quad$ sulphide inhibition kinetic constant

OLR organic loading rate

PBR packed bed reactor

$\mathrm{pH} \quad$ negative log of hydrogen ion activity

$\mathrm{pK}_{\mathrm{S} 1} \quad 1^{\text {st }}$ dissociation constant for the sulphide weak acid base system corrected for ionic strength

\footnotetext{
* To whom all correspondence should be addressed.

일 +2721 650 2585; fax: +2721 689 7471;

e-mail: George.Ekama@uct.ac.za

Received 13 January 2009; accepted in revised form 31 July 2009.
}

effects.

PSS primary sewage sludge

R1 UASB Reactor 1

R2 UASB Reactor 2

$\mathrm{R}_{\mathrm{s}} \quad$ sludge age

$\mathrm{S}_{\mathrm{bp}} \quad$ biodegradable particulate COD concentration

SBR sequencing batch reactor

SCFA short chain fatty acids

SLR sludge loading rate

SRB sulphate reducing bacteria

SRT solids retention time

SS steady state

SSD sample standard deviation

$\mathrm{S}_{\text {un }} \quad$ un-biodegradable particulate COD concentration

TKN total Kjeldahl nitrogen

Total Alk sum of weak acid/base subsystem alkalinities

UASB upflow anaerobic sludge bed reactor

UPO un-biodegradable particulate organics

USCOD un-biodegradable soluble COD

$\mathrm{V}_{\mathrm{b}} \quad$ bed volume

VFA volatile fatty acids

$\mathrm{V}_{\text {up }} \quad$ hydraulic upflow velocity in UASB reactor

\section{Introduction}

The feasibility of a novel system for BSR of AMD using PSS as carbon source in a UASB reactor configuration (R1) was described in Part 1 (Poinapen et al., 2009a). From the successful operation of the UASB reactor $\mathrm{R} 1$ at $35^{\circ} \mathrm{C}$ (fed 1500 $\mathrm{mgSO}_{4}^{2-/ \ell}$ for a period of $280 \mathrm{~d}$ ), the performance of BSR using PSS was evaluated also in a second identical UASB reactor $(\mathrm{R} 2)$ operated in parallel to $\mathrm{R} 1$ but at ambient $\left(20^{\circ} \mathrm{C}\right)$ 


\begin{tabular}{|c|c|c|c|c|}
\hline \multicolumn{5}{|c|}{$\begin{array}{l}\text { TABLE } 1 \\
\text { Summary of operational conditions for UASB reactor R2 during the } 270 \mathrm{~d} \text { of operation at } 20^{\circ} \mathrm{C} \\
\text { (see timeline Fig. } 2 \text { in Poinapen et al., 2009a) }\end{array}$} \\
\hline $\begin{array}{c}\text { Day of } \\
\text { investigation }\end{array}$ & \begin{tabular}{|c|} 
Day of \\
operation of R2 \\
\end{tabular} & Reactor status/activities performed & \begin{tabular}{|c|} 
HRT \\
(h)
\end{tabular} & $\begin{array}{c}\text { BRT } \\
\text { (h) }\end{array}$ \\
\hline $280-350$ & \begin{tabular}{|l|}
$1-70$ \\
\end{tabular} & Feed PSS COD to sulphate ratio 1.33 and sludge bed volume $7.1 \ell$ & & \\
\hline $280-330$ & $1-50$ & SRB acclimatisation & 28.0 & 21.8 \\
\hline $331-350$ & $51-70$ & R2 SS 1 & 28.0 & 25.5 \\
\hline $371-392$ & $91-112$ & R2 SS 2 & 24.0 & 21.8 \\
\hline 395-550 & $115-270$ & Feed PSS COD to sulphate ratio 1.75 and sludge bed volume $7.4 \ell$ & & \\
\hline $398-419$ & $118-139$ & R2 SS 3 & 24.0 & 22.8 \\
\hline $424-431$ & $144-151$ & R2 SS 4 & 22.0 & 20.9 \\
\hline $434-550$ & $154-270$ & R2 SS 5 & $20.4-21.0$ & 19.4-19.9 \\
\hline $406-435$ & $126-155$ & CHON elemental analysis of waste sludge & & \\
\hline $448 \& 463$ & $168 \& 183$ & Bed profile tests (both on solubles and solids) & & \\
\hline $448 \& 435$ & $168 \& 183$ & Determination of sludge age & $20.4-21.0$ & 19.4 \\
\hline $430-538$ & $150-258$ & $\mathrm{H}_{2} \mathrm{~S}$ gas capture and measurement* & $20.4-21.0$ & 19.4 \\
\hline $465-530$ & $185-250$ & Stopped $\mathrm{NaHCO}_{3}$ dosage to feed & $20.4-21.0$ & 19.4 \\
\hline $398-538$ & $118-258$ & $\mathrm{COD}, \mathrm{S}$ and $\mathrm{N}$ mass balances calculated & & \\
\hline
\end{tabular}

* $H_{2} S$ gas measurement done only when conducting sulphur mass balances over the system.

temperature. Accordingly, from Day 280 of the investigation, Reactor R2 $\left(\mathrm{T}=20^{\circ} \mathrm{C}\right)$ was operated with feed sulphate and PSS concentrations of $1500 \mathrm{mgSO}_{4}^{2-/ \ell}$ and $1995 \mathrm{mgCOD} / \ell$ respectively, representing a feed PSS COD to sulphate ratio of $1.33 \mathrm{mgCOD} / \mathrm{mgSO}_{4}{ }^{2-}$. This ratio for $\mathrm{R} 2$ was slightly higher than the $\mathrm{R} 1$ ratio of 1.25 because the hydrolysis/acidogenesis rate of PSS at $20^{\circ} \mathrm{C}$ is slower than at $35^{\circ} \mathrm{C}$, but how much slower was not known. Later on Day 395, the PSS COD/ $/ \mathrm{SO}_{4}{ }^{2-} \mathrm{R} 2$ ratio was increased to 1.75 (see Fig. 2 in Poinapen et al., 2009a) to reduce the effluent sulphate concentration to below 250 $\mathrm{mgSO}_{4}^{2-} / \ell$. In this paper, the operation and performance of UASB R2 at $20^{\circ} \mathrm{C}$ are assessed, evaluated and compared with that of UASB R1 at $35^{\circ} \mathrm{C}$.

After the feasibility study with R1 from Day 1 to 280 (Poinapen et al., 2009a), the influent sulphate concentration to R1 was increased from $1500 \mathrm{mgSO}_{4}{ }^{2-/ \ell}$ to 1800 $\mathrm{mgSO}_{4}{ }^{2-} / \ell$. It was expected that the higher feed sulphate concentration would result in a higher sulphide concentration in the system. Even though compared with other anaerobic micro-organisms (namely methanogenic archaea) the sulphate SRB have the highest tolerance to sulphide, their activity is nevertheless affected by the presence of sulphide, especially un-dissociated hydrogen sulphide $\left(\mathrm{H}_{2} \mathrm{~S}\right)$ Un-dissociated $\mathrm{H}_{2} \mathrm{~S}$ is inhibitory to SRB and decreases their growth activity (Reis et al., 1992; Maillacheruvu et al., 1993; Konishi et al., 1996; Kalyuzhnyi et al., 1997; O’Flaherty et al., 1998). Investigating the effect of high feed sulphate concentration on the system performance was therefore necessary in order to assess the extent of un-dissociated hydrogen sulphide $\left(\mathrm{H}_{2} \mathrm{~S}\right)$ inhibition on BSR using PSS as substrate in a UASB reactor.

\section{Methodology}

Reactor $\mathrm{R} 2\left(\mathrm{~T}=20^{\circ} \mathrm{C}\right)$ was inoculated with waste sludge from R1 (Day 280) and operated for $270 \mathrm{~d}$ to Day 550. Initially, R2 performance was not as good as R1, despite complete seeding with R1 sludge. The relatively short HRT of $\sim 28 \mathrm{~h}$ at which R2 was operated during the start-up period was probably too short. It was thought that R1 waste sludge would result in a quick and effective start-up of $\mathrm{R} 2$ biological processes since $\mathrm{R} 1$ was at its maximum efficiency. However, it appeared that an adaptation period was required for the selected population group of sulphidogens to develop at the lower temperature $\left(20^{\circ} \mathrm{C}\right)$. After $50 \mathrm{~d}$ of operation to Day 330, granulation was observed and the system performance started to stabilise. The effluent sulphate concentration remained stable from periods Day 333-350 and Day 371-392 with a sulphate removal of $83.7 \%$ and $79.8 \%$ respectively, even though the HRT was incrementally decreased from $28 \mathrm{~h}$ to $24 \mathrm{~h}$ (see Table 5 later), implying that the reactor was at steady state. However, the effluent sulphate concentration (303 $\left.\mathrm{mgSO}_{4}^{2-} / \ell\right)$ was still above the specified requirement (250 $\mathrm{mg} \mathrm{SO}_{4}^{2-/ \ell}$ in South Africa). In addition, during this period the VFA concentration was low suggesting that PSS hydrolysis was incomplete and was the rate-limiting step under the lower temperature conditions.

During the $270 \mathrm{~d}$ of operation of R2 (i.e. from investigation Day 280 to 538, or equivalently from R2 Day 0 to Day 258), the influent feed flow rate was varied to vary the HRT. The UASB R2 operational conditions during the $270 \mathrm{~d}$ are set out in Table 1. The different steady state periods with respect to the operating HRT with 2 PSS COD/ $/ \mathrm{SO}_{4}^{2-}$ ratios, the days at which bed profile tests were conducted, the period when alkalinity dosage was stopped and the days on which mass balances were determined are listed.

\section{Influent characteristics}

Similar to UASB Reactor R1 (Poinapen et al., 2009a), the prepared feed for R2 (from dilution of the PSS) augmented with $1500 \mathrm{mgSO}_{4}{ }^{2-} / \ell$ was regularly analysed for its COD, TKN, FSA, VFA and $\mathrm{H}_{2} \mathrm{CO}_{3}{ }^{*}$ alkalinity concentrations and $\mathrm{pH}$. Two influent PSS COD/ $\mathrm{SO}_{4}^{2-}$ ratios (namely 1.33 and $1.75 \mathrm{mg} \mathrm{COD} /$ $\mathrm{mgSO}_{4}{ }^{2-}$ ) were applied. A summary of the results from the measurements of the above parameters over the 2 steady state periods at feed $\mathrm{COD} / \mathrm{SO}_{4}{ }^{2-}$ ratio $=1.33(\mathrm{SS} 2, \mathrm{R} 2$ operation Day 371 to Day 392) and 1.75 (SS5, R2 operation Day 520 to Day 538) is listed in Table 2.

It was expected that at $20^{\circ} \mathrm{C}$, the hydrolysis/acidogenesis of biodegradable particulate organics (BPO) would not be complete but no information was available to indicate what 


\begin{tabular}{|c|c|c|c|c|}
\hline \multicolumn{5}{|c|}{$\begin{array}{c}\text { TABLE } 2 \\
\text { Summary of the influent characteristics of UASB reactor } \mathrm{R2}\left(1500 \mathrm{mgSO}_{4}{ }^{2-/ \ell} \text { at } 20^{\circ} \mathrm{C}\right) \text { for steady state (SS) } \\
\text { periods } 2 \text { and } 5\end{array}$} \\
\hline Feed PSS COD to sulphate ratio (mgCOD/mgSO ${ }_{4}{ }^{2-}$ ) & 1.33 & & 1.75 & \\
\hline Steady state period & SS 2 (R2 Day & $-392)$ & SS 5 (R2 Day & -538) \\
\hline Parameter & Average value & SSD1 $^{1}$ & Average value & SSD $^{1}$ \\
\hline Total COD $(\mathrm{mgCOD} / \ell)$ & 1975 & 7 & 2596 & 78 \\
\hline Unbiodegradable particulate COD $\left(\mathrm{f}_{\mathrm{PS}^{\prime} \mathrm{un}}=0.36\right)^{2}(\mathrm{mgCOD} / \ell)$ & 711 & - & 935 & - \\
\hline VFA (or SCFA) $(\mathrm{mgHAc} / \ell)^{3}$ & 123 & 7 & 158 & 11 \\
\hline Fermentable readily biodegradable $(\mathrm{FRBCOD}) \mathrm{COD}(\mathrm{mgCOD} / \ell)^{3,4}$ & 139 & - & 162 & - \\
\hline Slowly biodegradable COD $(\mathrm{mgCOD} / \ell)$ & 987 & - & 1322 & - \\
\hline Unbiodegradable soluble $(\mathrm{mgCOD} / \ell)^{5}$ & 7 & - & 8 & - \\
\hline $\mathrm{TKN}(\mathrm{mgN} / \ell)$ & 71 & 18 & 78 & 18 \\
\hline FSA $(\mathrm{mgN} / \ell)$ & 8 & 5 & 10 & 4 \\
\hline $\mathrm{H}_{2} \mathrm{CO}_{3}^{*}$ alkalinity $\left(\mathrm{mg} / \ell\right.$ as $\left.\mathrm{CaCO}_{3}\right)$ before dosage & 18 & 3 & 23 & 3 \\
\hline $\mathrm{H}_{2} \mathrm{CO}_{3}^{*}$ alkalinity $\left(\mathrm{mg} / \ell\right.$ as $\left.\mathrm{CaCO}_{3}\right)$ after dosage & 423 & 6 & 429 & 15 \\
\hline Total phosphorous $(\mathrm{mgP} / \ell)$ & 28 & - & 33 & - \\
\hline Ortho-phosphate $(\mathrm{mgP} / \ell)$ & 8 & - & 10 & - \\
\hline pH before dosage & 5.95 & 0.05 & 5.94 & 0.05 \\
\hline pH after dosage & 7.25 & 0.10 & - & - \\
\hline
\end{tabular}

${ }^{1} \mathrm{SSD}=$ Standard deviation

${ }^{2}$ Accepted from Ristow et al. (2006) for the same PSS source.

${ }^{3} \mathrm{VFA}$ and FRBCOD high due to fermentation in PSS during storage at $4^{\circ} \mathrm{C}$

${ }^{4}$ From membrane $(0.45 \mu \mathrm{m})$ filtered COD minus VFA and USCOD

${ }^{5}$ Un-biodegradable soluble COD (USCOD) very low-after dilution with tap water (>10 times)

PSS COD/SO ${ }_{4}^{2-}$ ratio was appropriate to supply the required VFA from the hydrolysis/acidogenesis of PSS at $20^{\circ} \mathrm{C}$. After a few trial ratios, it was found that a ratio of 1.75 appeared most favourable to supply sufficient VFA for BSR, i.e. effluent sulphate $<250 \mathrm{mg} \mathrm{SO}_{4}^{2-} / \ell$. The results obtained from the 1.33 and 1.75 ratios are discussed below. Also, towards the end of the experimental programme on UASB R2 (R2 Day 465 to 530), influent alkalinity $\left(\mathrm{NaHCO}_{3}\right)$ dosage $\left(\sim 400 \mathrm{mg} / \ell\right.$ as $\left.\mathrm{CaCO}_{3}\right)$ was stopped in order to ascertain the $\mathrm{pH}$ at which the system would stabilise itself.

\section{Results}

\section{Effluent sulphate concentration with time}

The variation in UASB R2 effluent sulphate concentration with time from R2 Day 290 is shown in Fig. 1 for the whole experimental period of $\mathrm{R} 2$ at the 2 feed PSS COD/ $/ \mathrm{SO}_{4}{ }^{2-}$ ratios. For the period R2 Day 331 to Day 392 (comprising SS Periods 1 and 2), on average the effluent sulphate was not reduced below $250 \mathrm{mgSO}_{4}{ }^{2-} / \ell$ because of the low PSS COD/ $/ \mathrm{SO}_{4}{ }^{2-}$ ratio (1.33) and consequently low VFA generation by hydrolysis/acidogenesis. From R2 Day 395 onwards the feed $\mathrm{COD} / \mathrm{SO}_{4}{ }^{2-}$ ratio was increased to 1.75 which resulted in a marked decrease in the effluent sulphate concentration to around $100 \mathrm{mgSO}_{4}{ }^{2-/ \ell}$. Clearly VFA generation via hydrolysis/ acidogenesis was the limiting rate for BSR.

\section{Effluent $\mathrm{H}_{2} \mathrm{CO}_{3}{ }^{*}$ alk, Alk $\mathrm{H}_{2} \mathrm{~S}$ and VFA concentrations with time}

As expected, the effluent total Alk (sum of $\mathrm{H}_{2} \mathrm{CO}_{3} *$ alk, Alk $\mathrm{H}_{2} \mathrm{~S}$ and Alk VFA) increased due to the increase in the PSS $\mathrm{COD} / \mathrm{SO}_{4}{ }^{2-}$ ratio (R2 Day 395 to Day 450 in Fig. 2) as a direct consequence of an increase in sulphate reduced, hence increasing the total sulphide $\left(\mathrm{S}_{\mathrm{T}}=\mathrm{H}_{2} \mathrm{~S}+\mathrm{HS}^{-}\right)$, dissociated sulphide

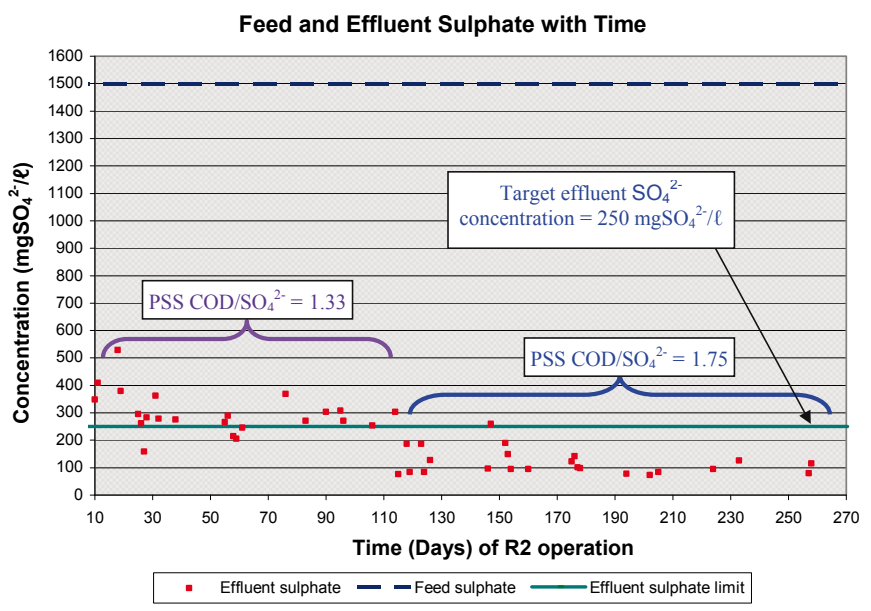

Figure 1

Effluent sulphate concentration-time profiles with PSS as substrate augmented with $1500 \mathrm{mgSO}_{4}^{2-/ / \ell}$ sulphate (R2)

(HS-) and $\mathrm{Alk}_{2} \mathrm{~S}$ (proportional to $\mathrm{HS}^{-}$) concentrations.

The data points circled in Fig. 2 represent the period (R2 Day 475 onwards) over which the feed $\mathrm{NaHCO}_{3}$ dosage was progressively decreased to zero by R2 Day 510 . This elimination of feed alkalinity dosage did not affect the system performance in any way as shown in Figs. 1 and 2 by the low sulphate and VFA concentrations. This is an important result for the UASB BSR performance as it shows that BSR:

- Occurs successfully at low temperature $\left(20^{\circ} \mathrm{C}\right)$

- Regulates the reactor $\mathrm{pH}$ near neutrality $(\sim 7)$ by itself even though the sulphate rich AMD is acidic. This is because the BSR bioprocesses reduce sulphate to sulphide and take up 2 protons $\left(\mathrm{H}^{+}\right)$per mole $\mathrm{SO}_{4}^{2-}$, i.e. $\mathrm{SO}_{4}^{2-}+2 \mathrm{H}^{+}+8\left(\mathrm{H}^{+}+\mathrm{e}^{-}\right.$, supplied by the organics) $\rightarrow \mathrm{H}_{2} \mathrm{~S}+4 \mathrm{H}_{2} \mathrm{O}$. 


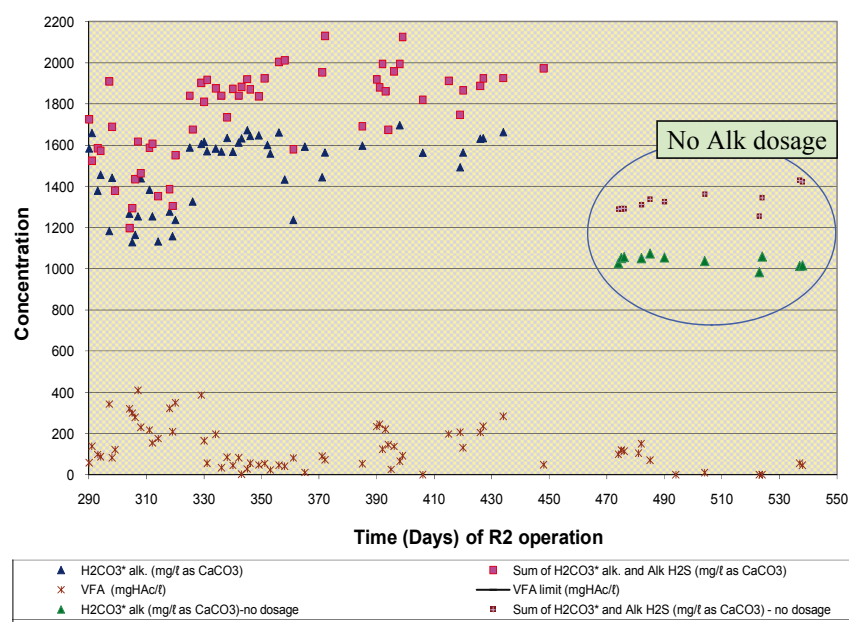

Figure 2

Effluent alkalinity and VFA concentration-time profiles with PSS as substrate augmented with $1500 \mathrm{mgSO}_{4}^{2-/ / l}$ sulphate (R2)

The stoichiometry of BSR with organics in general and PSS in particular, are considered in Part 5 of this series, currently in preparation by Poinapen and Ekama.

\section{Reactor performance with $\mathrm{COD} / \mathrm{SO}_{4}{ }^{2-}$ ratio of 1.33}

Table 3 shows the performance of UASB Reactor R2 when operated at an HRT of $24 \mathrm{~h}$ (SS2). It can be seen that R2 performed satisfactorily because it achieved a sulphate removal efficiency of $\sim 80 \%( \pm 2 \%)$ and an organic removal efficiency of $\sim 77 \%$ ( $\pm 1 \%$ ). However, despite the relatively high sulphate removal efficiency, the average effluent sulphate remained above the upper limit of $250 \mathrm{mgSO}_{4}^{2-/ \ell}$. The cause for this fairly high effluent sulphate concentration $\left(\sim 303 \mathrm{mgSO}_{4}^{2-/ \ell}\right)$ was attributed to the unavailability of sufficient VFA which remained very low in the effluent, despite the higher feed PSS $\mathrm{COD} / \mathrm{SO}_{4}{ }^{2-}$ ratio of 1.33 compared with the 1.25 of $\mathrm{R} 1$. It was concluded that at low temperature, the hydrolysis rate of the PSS biodegradable particulate organics (BPO) was reduced thereby generating insufficient VFA and $\mathrm{H}_{2}$ for sulphate reduction.

In order to increase the production of VFA, the PSS COD/ $\mathrm{SO}_{4}{ }^{2-}$ ratio was increased to 1.75 which increased the feed BPO COD concentration and consequently the concentration of BPO hydrolysed, thereby generating more VFA and $\mathrm{H}_{2}$ for BSR.
Increasing the $\mathrm{PSS} \mathrm{COD} / \mathrm{SO}_{4}{ }^{2-}$ ratio also resulted in higher un-biodegradable particulate organics (UPO, $\left.\mathrm{S}_{\mathrm{up}}\right)$ and $\mathrm{BPO}\left(\mathrm{S}_{\mathrm{bp}}\right)$ not hydrolysed. Hence more particulate organics needed to be wasted to maintain the bed volume. So to provide a larger bed volume (and concomitantly a longer sludge age), the reactor sludge bed volume (and height) was increased from 7.1 to $7.4 \ell$. The increased sludge age allowed more time for the BPO to be hydrolysed as PSS hydrolysis is the rate-limiting process.

\section{R2 performance with a PSS COD/SO ${ }_{4}^{2-}$ ratio of 1.75 at lowest optimal HRT of 20.4 to $21.0 \mathrm{~h}$}

At the higher feed PSS COD/SO ${ }_{4}^{2-}$ ratio of 1.75 , the performance of R2 improved to the extent that the effluent quality concentrations were now met (i.e. sulphate $<250 \mathrm{mgSO}_{4}^{2-/ \ell}$ and VFA $<100 \mathrm{mgHAc} / \ell$ ). The performance of UASB Reactor $\mathrm{R} 2$ at the lowest optimal HRT of 20.4 to $21.0 \mathrm{~h}$ with alkalinity dosage $\left(\sim 424 \mathrm{mg} / \ell\right.$ as $\left.\mathrm{CaCO}_{3}\right)$ from R2 Day 434 to Day 464 (SS period 5a) was good (see Table 4) with an average sulphate removal efficiency of $93.3 \pm 1.5 \%$.

Influent alkalinity $\left(\mathrm{NaHCO}_{3}\right)$ dosage was discontinued from R2 Day 465 to the end of the experimental programme on R2 Day 550. Table 4 lists also the effluent parameter values when R2 was operated at an HRT of between $20.4 \mathrm{~h}$ and $21.0 \mathrm{~h}$ with no alkalinity dosage to the feed for the period Day 520 to Day 538. With the supply of additional carbon (i.e. more PSS), the sulphate removal efficiency increased from $80 \%( \pm 2.0 \%)$, when fed a PSS $\mathrm{CO} / \mathrm{SO}_{4}{ }^{2-}$ ratio of 1.33 , to $>93 \%( \pm 1.3 \%)$, with PSS COD/ $\mathrm{SO}_{4}{ }^{2-}$ ratio of 1.75 . From the high organic COD removal efficiency of $91 \%( \pm 1.3 \%)$ it was found that the increase in PSS to meet the VFA demand did not impact the effluent quality in terms of suspended solids. In fact, the particulate organic COD concentration remained low with an average value of $138( \pm 25) \mathrm{mgCOD} / \ell$.

The aqueous sulphide concentration $\left(\mathrm{S}_{\mathrm{T}}=\mathrm{H}_{2} \mathrm{~S}+\mathrm{HS}^{-}\right)$was measured via the COD with the modified method described by Poinapen et al. (2009b). This sulphide concentration matched very closely the theoretical sulphide produced from the sulphate reduced (see below for $\mathrm{S}$ mass balance). In addition, discontinuing the alkalinity dosage to the influent (from R2 for the period Day 468 to Day 550) did not affect the system performance in any way. The alkalinity produced by the BSR increased the $\mathrm{pH}$ from the influent value of 5.94 to a reactor value of 7.21. This shows that the system is $\mathrm{pH}$ self-regulatory, which is a major advantage of BSR to reduce the cost of chemical dosing in AMD treatment.

\begin{tabular}{|c|c|c|c|c|}
\hline $\begin{array}{r}\text { TA } \\
\text { Effluent characteristics of UASB reactor } R \\
1.33 \mathrm{mgCOD} / \mathrm{mgSO}_{4}{ }^{2-} \text { at an }\end{array}$ & $\begin{array}{l}\text { BLE } 3 \\
\text { ? with an influe } \\
\text { IRT of } 24 \mathrm{~h} \text { (be }\end{array}$ & $\begin{array}{l}\text { SS C } \\
\text { lume }\end{array}$ & $\begin{array}{l}\text { sulphate rati } \\
\text { e) }\end{array}$ & \\
\hline Steady state (SS) period 2 (R2 Day 371 to Day 392) & Influ & & Efflu & \\
\hline Parameter & Average value & SSD & Average value & SSD \\
\hline Total organic COD $(\mathrm{mgCOD} / \ell)$ & 1975 & 7 & 453 & 13 \\
\hline Organic soluble COD $(\mathrm{mgCOD} / \ell)$ & 277 & 7 & 146 & 8 \\
\hline Particulate COD $(\mathrm{mgCOD} / \ell)$ & 1698 & 7 & 307 & 9 \\
\hline VFA (or SCFA) (mgCOD/ $\ell$ ) & 131 & 7 & 49 & 20 \\
\hline $\mathrm{H}_{2} \mathrm{CO}_{3} *$ alkalinity $\left(\mathrm{mg} / \ell\right.$ as $\left.\mathrm{CaCO}_{3}\right)$ after dosage & 424 & 7 & 1553 & 25 \\
\hline $\mathrm{pH}$ & $7.25^{\mathrm{a}}$ & 0.10 & 7.21 & 0.02 \\
\hline Sulphate $\left(\mathrm{mgSO}_{4}^{2-/ \ell}\right)$ & 1500 & - & 303 & 30 \\
\hline Aqueous sulphide $(\mathrm{mgS} / \ell)$ & 0 & - & 216 & 5 \\
\hline Theoretical aqueous sulphide from sulphate reduced $(\mathrm{mgS} / \ell)$ & - & - & 399 & 11 \\
\hline
\end{tabular}

a: Feed $\mathrm{pH}$ after dosage with $\mathrm{NaHCO}_{3}$ 


\begin{tabular}{|c|c|c|c|c|c|c|}
\hline \multicolumn{7}{|c|}{$\begin{array}{c}\text { TABLE } 4 \\
\text { Effluent characteristics of UASB reactor R2 at a feed PSS COD to sulphate ratio of } 1.75 \mathrm{mgCOD} / \mathrm{mgSO}_{4}{ }^{2-} \\
\text { at the lowest optimal HRT of } 20.4-21.0 \mathrm{~h}(\text { Bed volume }=7.4 \mathrm{l}) \text { with and without alkalinity dosage to feed } \\
\text { (SS period 5, R2 Day } 434 \text { to Day } 538)\end{array}$} \\
\hline \multirow{3}{*}{$\begin{array}{l}\text { Steady state (SS) period } 5 \text { (Day } 434 \text { to Day 538) } \\
\text { Parameters }\end{array}$} & \multirow{2}{*}{\multicolumn{2}{|c|}{ Influent }} & \multirow{2}{*}{\multicolumn{2}{|c|}{$\begin{array}{c}\text { Steady state (SS) } \\
\text { period 5a (R2 Day } 434 \\
\text { to Day 464) } \\
\text { (Alk dosage) } \\
\text { Effluent }\end{array}$}} & \multirow{2}{*}{\multicolumn{2}{|c|}{$\begin{array}{c}\text { Steady state (SS) } \\
\text { period 5b (R2 Day } 520 \\
\text { to Day 538) } \\
\text { (No Alk dosage) } \\
\text { Effluent }\end{array}$}} \\
\hline & & & & & & \\
\hline & $\begin{array}{c}\text { Average } \\
\text { value }\end{array}$ & SSD & $\begin{array}{c}\text { Average } \\
\text { value }\end{array}$ & SSD & $\begin{array}{c}\text { Average } \\
\text { value }\end{array}$ & SSD \\
\hline Total organic COD $(\mathrm{mgCOD} / \ell)$ & 2596 & 44 & 664 & 102 & 234 & 27 \\
\hline Organic soluble $\mathrm{COD}(\mathrm{mgCOD} / \ell)$ & 339 & 17 & 305 & 66 & 96 & 8 \\
\hline Particulate COD $(\mathrm{mgCOD} / \ell)$ & 2257 & - & 359 & 42 & 138 & 25 \\
\hline VFA (or SCFA) $(\mathrm{mgCOD} / \ell)$ & 158 & 13 & 105 & 47 & 62 & 11 \\
\hline Sulphate $\left(\mathrm{mgSO}_{4}^{2-/ \ell}\right)$ & 1500 & - & 109 & 18 & 101 & 19 \\
\hline Sum of $\mathrm{H}_{2} \mathrm{CO}_{3}{ }^{*}$ alk. and $\mathrm{Alk} \mathrm{H}_{2} \mathrm{~S}\left(\mathrm{mg} / \ell\right.$ as $\left.\mathrm{CaCO}_{3}\right)$ & $424^{\mathrm{a}} / 23^{\mathrm{b}}$ & $11 / 3$ & 1920 & 27 & 1558 & 14 \\
\hline 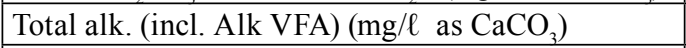 & $548^{\mathrm{a}} / 148^{\mathrm{b}}$ & $11 / 9$ & 2007 & 29 & 1610 & 13 \\
\hline $\mathrm{H}_{2} \mathrm{CO}_{3} *$ alkalinity $\left(\mathrm{mg} / \ell\right.$ as $\left.\mathrm{CaCO}_{3}\right)$ & $424^{\mathrm{a}} / 23^{\mathrm{b}}$ & $11 / 3$ & 1589 & 11 & 1144 & 10 \\
\hline $\mathrm{TKN}(\mathrm{mgN} / \ell)$ & 78 & 18 & 63 & 9 & 63 & 9 \\
\hline FSA $(\mathrm{mgN} / \ell)$ & 9.6 & 4 & 37 & 12 & 38 & 5 \\
\hline $\mathrm{pH}$ & 5.94 & 0.04 & 7.22 & 0.02 & 7.21 & 0.02 \\
\hline Aqueous sulphide $(\mathrm{mgS} / \ell)$ & 0 & - & $344^{\mathrm{c}}$ & 39 & 427 & 5 \\
\hline $\mathrm{H}_{2} \mathrm{~S}$ gas in reactor head space $(\mathrm{mgS} / \ell$ influent $)$ & 0 & - & 1.5 & 1.0 & 2.1 & 0.3 \\
\hline Theoretical sulphide from sulphate reduced $(\mathrm{mgS} / \ell)$ & 0 & - & 464 & 6 & 466 & 6 \\
\hline
\end{tabular}

TABLE 5

Sulphate and organic COD removal (\%) under steady state conditions at each HRT and BRT

\begin{tabular}{|l|c|c|c|c|c|c|c|c|}
\hline $\begin{array}{l}\text { Period of } \\
\text { operation }\end{array}$ & SS period & HRT (h) & BRT (h) & $\begin{array}{c}\text { Feed flow } \\
\text { rate (l/d) }\end{array}$ & $\begin{array}{c}\text { Organic } \\
\text { loading } \\
\text { rate (g } \\
\text { COD/d) }\end{array}$ & $\begin{array}{c}\text { Sulphate } \\
\text { loading } \\
\text { rate (g } \\
\text { SO } / \mathbf{d})\end{array}$ & $\begin{array}{c}\text { Sulphate } \\
\text { removal (\%) }\end{array}$ & $\begin{array}{c}\text { Organic } \\
\text { COD } \\
\text { removal (\%) }\end{array}$ \\
\hline Days 333-350 & 1 & 28.0 & $25.8^{\mathbf{b}}$ & 6.7 & 13.06 & 10.03 & 83.7 & 75.9 \\
\hline Days 371-392 & 2 & 24.0 & $22.1^{\mathbf{c}}$ & 7.8 & 19.88 & 11.70 & 79.8 & 76.8 \\
\hline Days 398-419 & 3 & 24.0 & $22.2^{\mathbf{c}}$ & 7.8 & 20.20 & 11.70 & 91.1 & 80.1 \\
\hline Days 424-431 & 4 & 20.8 & $19.2^{\mathbf{c}}$ & 9.0 & 23.28 & 13.48 & 88.2 & 74.6 \\
\hline Days 434-464 & $5 \mathrm{a}$ & 20.5 & $19.4^{\mathbf{c}}$ & 9.1 & 24.14 & 13.70 & 92.7 & 75.2 \\
\hline Days 520-538d & $5 \mathrm{~b}$ & 20.4 & $19.4^{\mathbf{c}}$ & 9.2 & 24.71 & 13.76 & 93.3 & 91.2 \\
\hline Days 398-419 & 3 & 24.0 & $22.2^{\mathbf{c}}$ & 7.8 & 20.20 & 11.70 & 91.1 & 80.1 \\
\hline Days 424-431 & 4 & 20.8 & $19.2^{\mathbf{c}}$ & 9.0 & 23.28 & 13.48 & 88.2 & 74.6 \\
\hline Days 434-464 & $5 \mathrm{a}$ & 20.5 & $19.4^{\mathbf{c}}$ & 9.1 & 24.14 & 13.70 & 92.7 & 75.2 \\
\hline Days 520-538d & $5 \mathrm{~b}$ & 20.4 & $19.4^{\mathbf{c}}$ & 9.2 & 24.71 & 13.76 & 93.3 & 91.2 \\
\hline
\end{tabular}

a: HRT calculated at a liquid volume of $7.8 \ell$

b: BRT calculated at sludge volume of $7.1 \ell$ with feed PSS COD to Sulphate ratio of 1.33

c: BRT calculated at sludge volume of $7.4 \ell$ with feed PSS COD to Sulphate ratio of 1.75

d: $\mathrm{No} \mathrm{NaHCO}_{3}$ dosage to influent

\section{Summary of UASB R2 performance}

A summary of the average experimental data at the different HRTs and BRTs is listed in Table 5. The minimum HRT for which the specified effluent criteria were met was found to be between 20.4 to $21.0 \mathrm{~h}$, where sulphate removal efficiency was $\sim 95 \%$ at a PSS COD $/ \mathrm{SO}_{4}{ }^{2-}$ ratio of 1.75 .

\section{Profile of solids - Calculation of sludge age $\left(R_{s}\right)$}

Figure 3 illustrates the variation of R2 solids concentration along the bed axis. Above the $10 \mathrm{~cm}$ height there is little difference in the solids concentration along the bed axis probably largely due to the sludge recycle (at half the influent flow). From these measurements, the mass of sludge in the bed was calculated, which in relation to the mass of sludge wasted (see below) and the mass of sludge in the effluent, yielded the sludge age $\left(\mathrm{R}_{\mathrm{s}}\right)$ of the UASB Reactor R2 at around $24.1 \mathrm{~d}$.

\section{Analysis of R2 waste sludge}

UASB R2 waste sludge was analysed on 6 operational days 


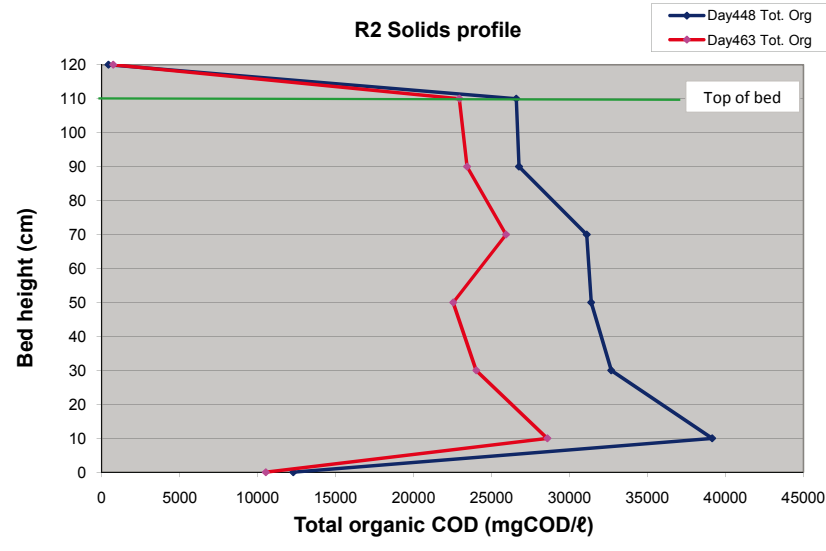

Figure 3

UASB Reactor $R 2$ sludge COD concentration profiles up the sludge bed height $(110 \mathrm{~cm})$ for a BRT of $19.3 \mathrm{~h}$ on R2 Day 448 and Day 463

(Table 6) and was found to have an average particulate organic COD/VSS $\left(f_{c v}\right)$ and TKN/VSS $\left(f_{n}\right)$ of $1.611 \pm 0.041$ and 0.068 \pm 0.016 respectively.

\section{Mass balances on R2}

Mass balances were conducted on R2 to check experimental data reliability. Similar to UASB R1 when fed 1500 $\mathrm{mgSO}_{4}^{2-/ \ell}$ during the first $280 \mathrm{~d}$ (Poinapen et al., 2009a), prior to the modification of the analytical procedures for accurate measurement of aqueous sulphide, the R2 system COD mass balance was relatively low $(91.7 \pm 5.2 \%)$ while the $\mathrm{S}$ mass balance was poor $(69.4 \pm 6.4 \%)$. However, these mass balances, particularly the $\mathrm{S}$ mass balance, improved considerably with the modified analytical method for $\mathrm{H}_{2} \mathrm{~S}$ measurement. The COD mass balance increased to $98.0 \%( \pm 0.2 \%)$ while the $\mathrm{S}$ mass balance averaged $95.9 \%( \pm 0.2 \%)$. These good mass balances confirm the reliability of the measured data and the modified methods for aqueous $\mathrm{H}_{2} \mathrm{~S}$ measurement (Poinapen et al., 2009b). Nitrogen (N) mass balance was also very good and averaged $104.5( \pm 4.9 \%)$.

\section{Operation and performance of R1 fed 1800 $\mathrm{mgSO}_{4}{ }^{2-1 / \ell}$}

During the initial phase of this investigation (R1 Day 0 to Day
280), the design and operational parameters for UASB R1 $\left(\mathrm{T}=35^{\circ} \mathrm{C}\right.$ ) fed $1500 \mathrm{mgSO}_{4}{ }^{2-} / \ell$ were established (R1 Day 1 to Day 280, Poinapen et al., 2009a). Sulphate, $\mathrm{H}_{2} \mathrm{CO}_{3}{ }^{*}$ alkalinity and VFA concentration profiles through the sludge bed were conducted to gain insight into the bioprocess behaviour along the reactor bed. Solids profile tests were used to determine the sludge age of the system at the minimum HRT (13.5 to $14.0 \mathrm{~h}$ ) at which effluent quality criteria were met (i.e. effluent sulphate $<250 \mathrm{mgSO}_{4}{ }^{2-} / \ell$ and effluent VFA $<100 \mathrm{mgHAc} / \ell$ ). After the initial phase of R1, the influent sulphate was increased to $1800 \mathrm{mgSO}_{4}^{2-/ \ell}$ on R1 Day 280 to investigate the effect of higher sulphate concentration on the system. It is well documented that the biological treatment of sulphate-rich wastewater involves the potential effect of sulphide inhibition on bacterial growth and activity. [In the BioSURE ${ }^{\circledR}$ process design for AMD treatment, the treated effluent is recycled to blend with the raw AMD. The high alkalinity (sulphide and carbonate alkalinities) in the recycle stream neutralises the $\mathrm{pH}$, precipitates the heavy metals and almost halves the inflow sulphate concentration of the raw AMD. Therefore, in a situation where an effluent sulphate of $200 \mathrm{mgSO}_{4}^{2-/ \ell}$ is recycled on a 1:1 effluent to incoming raw AMD flow rates, the raw AMD can have a feed sulphate concentration of up to $3400 \mathrm{mgSO}_{4}^{2-/ \ell}$ ]. Operating R1 with a higher feed sulphate of $1800 \mathrm{mgSO}_{4}^{2-/ \ell}$ gave insight into the extent of sulphide inhibition on the bioprocesses in the system. The feed PSS COD concentration was also increased to conform to a feed PSS COD/sulphate ratio of $1.44 \mathrm{mgCOD} / \mathrm{mgSO}_{4}^{2-}$. This higher ratio than 1.25 was applied to ensure that BSR in the system was not VFA limited. The operation and performance of R1 at 1 $800 \mathrm{mgSO}_{4}^{2-/ \ell}$ are described and analysed below.

\section{R1 experimental programme (fed $1800 \mathrm{mgSO}_{4}^{2-/ \ell}$ )}

R1 was fed $1800 \mathrm{mgSO}_{4}^{2-/ \ell}$ from Day 281 to Day 530 (the day it was stopped). It took around $20 \mathrm{~d}$ for the reactor to reach the first steady state at which the effluent sulphate concentration $\left(<250 \mathrm{mgSO}_{4}^{2-/ \ell}\right)$ was met at an HRT of $19 \mathrm{~h}$. Thereafter, the HRT was gradually decreased (by increasing the influent flow rate) to establish the lowest optimal HRT. It was found that at an HRT below $18 \mathrm{~h}$, the effluent sulphate concentration could not be maintained below $250 \mathrm{mgSO}_{4}^{2-} / \ell$ either due to sludge bed expansion (which reduces the bed sludge age) and/or insufficient sulphate contact time with the biomass. Accordingly, the lowest HRT was set at 18.0 to $18.5 \mathrm{~h}$. The BRT was 16.4 to $16.8 \mathrm{~h}$ based on a sludge bed volume of $7.1 \mathrm{C}$ and the upflow velocity, $\mathrm{V}_{\text {up }}$, was 0.093 to $0.096 \mathrm{~m} / \mathrm{h}$. The sludge age determined from the bed profile test was $21 \mathrm{~d}$. The various

\begin{tabular}{|c|c|c|c|c|c|c|c|c|c|}
\hline \multicolumn{10}{|c|}{$\begin{array}{c}\text { TABLE } 6 \\
\text { Analysis of waste sludge from the UASB Reactor R2 (fed } 1500 \mathrm{mgSO}_{4}{ }^{2-/ \ell} \text { ) }\end{array}$} \\
\hline $\begin{array}{l}\text { Day of } \\
\text { operation }\end{array}$ & $\begin{array}{c}\text { Total } \\
\text { COD } \\
\text { (mgCOD/e) }\end{array}$ & $\begin{array}{c}\text { Particulate } \\
\text { COD } \\
\text { (mgCOD/e) }\end{array}$ & $\begin{array}{l}\text { TSS } \\
(\mathrm{mg} / \mathrm{l})\end{array}$ & $\begin{array}{l}\text { VSS } \\
(\mathrm{mg} / \ell)\end{array}$ & $\begin{array}{c}\text { TKN } \\
(\mathrm{mgN} / \ell)\end{array}$ & $\begin{array}{c}\text { COD/VSS } \\
\left(f_{c v}\right)\end{array}$ & $\begin{array}{l}\text { TKN/VSS } \\
\left(f_{n}\right)\end{array}$ & $\begin{array}{c}\text { Volume } \\
\text { wasted } \\
\text { per day*, } \\
Q_{w}(\ell / d)\end{array}$ & $\begin{array}{l}\text { Operating } \\
\text { sludge } \\
\text { age (d) }\end{array}$ \\
\hline 398 & 21336 & 20056 & 16120 & 12368 & 798 & 1.622 & 0.065 & 0.35 & 22.4 \\
\hline 406 & 20117 & 18862 & 14798 & 11378 & 1113 & 1.658 & 0.098 & 0.35 & 22.4 \\
\hline 419 & 28651 & 27174 & 22138 & 16906 & 1361 & 1.607 & 0.080 & 0.30 & 26.2 \\
\hline 426 & 32458 & 30977 & 26398 & 20150 & 1005 & 1.537 & 0.050 & 0.32 & 24.5 \\
\hline 427 & 27418 & 25745 & 21466 & 16220 & 980 & 1.587 & 0.060 & 0.40 & 20.0 \\
\hline 434 & 37498 & 35832 & 28340 & 21648 & 1253 & 1.655 & 0.058 & 0.31 & 25.3 \\
\hline Mean & 27913 & 26441 & 21543 & 16445 & 1085 & 1.611 & 0.068 & 0.34 & 23.5 \\
\hline SSD & 6019 & 5888 & 4917 & 3727 & 185 & 0.041 & 0.016 & 0.03 & 2.1 \\
\hline
\end{tabular}

* This was the volume of sludge wasted per day on these 6 analysis days. The average volume wasted daily over this operational period was $0.34 \mathrm{\ell} / \mathrm{d}$ to maintain the sludge bed volume at $7.4 \mathrm{\ell}$. 


\begin{tabular}{|c|c|c|c|}
\hline \multicolumn{4}{|c|}{$\begin{array}{l}\text { TABLE } 7 \\
\begin{array}{l}\text { Summary of operational conditions for UASB Reactor R1 fed } 1800 \mathrm{mgSO}_{4}{ }^{2} / \mathrm{l} \text { during the } 250 \mathrm{~d} \\
\text { of operation at } 35^{\circ} \mathrm{C}\end{array}\end{array}$} \\
\hline Day of operation & Reactor status/activities performed & HRT (h) & BRT (h) \\
\hline $281-530$ & Feed PSS COD to sulphate ratio 1.44 and sludge bed volume $7.1 \ell$ & & \\
\hline $302-330$ & R1 Steady state (SS) 1 & 19.0 & 17.1 \\
\hline $365-530$ & R1 SS 2 & $18.0-18.5$ & $16.4-16.8$ \\
\hline $\begin{array}{l}295,297,302,304,306,326,332, \\
389 \text { and } 478\end{array}$ & Bed profile tests (both on solubles and solids) & $18.0-19.0$ & $16.4-17.1$ \\
\hline $362-478$ & $\mathrm{H}_{2} \mathrm{~S}$ gas capture and measurement* & $18.0-19.0$ & $16.4-17.1$ \\
\hline $400-473$ & Stopped $\mathrm{NaHCO}_{3}$ dosage to feed & $18.0-18.5$ & $16.4-16.8$ \\
\hline $475-530$ & Stopped sludge recycle line & $18.0-18.5$ & $16.4-16.8$ \\
\hline $362-478$ & $\mathrm{COD}, \mathrm{S}$ and $\mathrm{N}$ mass balances calculated & $18.0-18.5$ & $16.4-16.8$ \\
\hline $295,297,304,306,332$ and 389 & Determination of sludge age & $18.0-19.0$ & $16.4-17.1$ \\
\hline $525-530$ & Batch tests on R1 sludge samples & & \\
\hline Sludge on Days 460 and 461 & Measurement of settling rates of solid particles in sludge & & \\
\hline
\end{tabular}

* $H_{2} S$ gas measurement done only when conducting sulphur mass balances over the system. This was done once because $\% \mathrm{~S}$ mass exiting as $\mathrm{H}_{2} \mathrm{~S}$ gas was negligible.

\begin{tabular}{|c|c|c|c|c|}
\hline $\begin{array}{r}\text { Effluent characteristics of UASB reactor } \\
\text { with no alkalin }\end{array}$ & $\begin{array}{l}\text { BLE } 8 \\
\text { 21 at the lowes } \\
\text { ity dosage to } f\end{array}$ & timal & of 18.0 to 18.5 & \\
\hline Steady state (SS) period 2 (R1 Day 420-473) & Infle & & Efflt & \\
\hline Parameter & Average value & SSD & Average value & SSD \\
\hline Total organic COD $(\mathrm{mgCOD} / \ell)$ & 2584 & 42 & 460 & 81 \\
\hline Organic soluble $\mathrm{COD}(\mathrm{mgCOD} / \ell)$ & 337 & 6 & 229 & 18 \\
\hline Particulate COD $(\mathrm{mgCOD} / \ell)$ & 2249 & 54 & 231 & 72 \\
\hline VFA (or SCFA) (mgCOD/ $\ell$ ) & 158 & 10 & 72 & 36 \\
\hline Sulphate $\left(\mathrm{mgSO}_{4}{ }^{2}-/ \ell\right)$ & 1800 & - & 146 & 51 \\
\hline Sum of $\mathrm{H}_{2} \mathrm{CO}_{3}{ }^{*}$ alkalinity and $\mathrm{Alk} \mathrm{H}_{2} \mathrm{~S}\left(\mathrm{mg} / \ell\right.$ as $\left.\mathrm{CaCO}_{3}\right)$ & 22 & 3 & 1855 & 73 \\
\hline $\mathrm{H}_{2} \mathrm{CO}_{3} *$ alkalinity $\left(\mathrm{mg} / \ell\right.$ as $\left.\mathrm{CaCO}_{3}\right)$ & 22 & 3 & 1358 & 6 \\
\hline $\mathrm{TKN}(\mathrm{mgN} / \ell)$ & 76 & 7 & 55 & 7 \\
\hline $\mathrm{FSA}(\mathrm{mgN} / \ell)$ & 9 & 6 & 46 & 12 \\
\hline $\mathrm{pH}$ & 5.99 & 0.05 & 7.08 & 0.02 \\
\hline Aqueous sulphide (mgS/ $/$ ) & 0 & - & 502 & 25 \\
\hline $\mathrm{H}_{2} \mathrm{~S}$ gas $(\mathrm{mgS} / \ell)$ & 0 & - & 1.1 & 0.4 \\
\hline Elemental sulphur in sludge (mgS/ $/$ sludge) & 0 & - & 21 & 2 \\
\hline Theoretical aqueous sulphide from sulphate reduced ( $\mathrm{mgS} / \ell$ ) & 0.0 & - & 539 & 23 \\
\hline
\end{tabular}

experimental stages and tests conducted on R1 (fed 1800 $\mathrm{mgSO}_{4}^{2-} / \ell$ ) including batch tests during the experimental period from Day 281 to Day 530 are listed in Table 7.

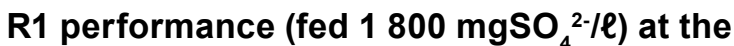 lowest optimal HRT of 18.0 to $18.5 \mathrm{~h}$}

Table 8 summarises the concentrations of the effluent parameters of interest when R1 (fed $1800 \mathrm{mgSO}_{4}^{2-/ \ell}$ ) was operated at its lowest optimal HRT of 18.0 to $18.5 \mathrm{~h}$ (Day 420 to Day 473). The influent values are also listed including $\mathrm{pH}$ because alkalinity was not dosed to the influent during this period.

The low effluent organic COD, sulphate and VFA concentrations with the concomitant production of high alkalinity underline the very good performance of R1 even at a relatively low HRT and no alkalinity dosage to the feed. The system achieved $\sim 92 \%$ sulphate removal efficiency implying that inhibition of un-dissociated hydrogen sulphide on the growth and activity of SRB was negligible. This aspect is important in calibrating the value of hydrogen sulphide inhibition constant
$\left(\mathrm{K}_{\mathrm{I}}\right)$ in the calibration and validation of the dynamic kinetic BSR model (UCTADM1-BSR) (to be presented in Part 6 of this series; currently in preparation by Poinapen and Ekama). Interestingly, the reactor/effluent $\mathrm{pH}$ was very close to the $\mathrm{pK}_{\mathrm{S1}}$ value of the $\mathrm{H}_{2} \mathrm{~S} / \mathrm{HS}^{-}$system suggesting that in the absence of gaseous $\mathrm{CO}_{2}$ production, the system $\mathrm{pH}$ is governed by the sulphide system. This aspect will be explored in greater depth in the steady state model development to be presented in Part 5 (currently in preparation by Poinapen and Ekama). Importantly for model development, the aqueous hydrogen sulphide recovery matches closely the theoretical sulphide from the sulphate reduced and COD, S and $\mathrm{N}$ mass balances were all very good averaging $96.5( \pm 0.8), 95.8( \pm 2.9)$ and $103.3( \pm 8.3)$ respectively.

With the excellent performance of R1 from Day 280 to Day 400 when fed $1800 \mathrm{mgSO}_{4}^{2-/ \ell}$ (detailed results not given), $\mathrm{NaHCO}_{3}$ dosage to the feed was stopped on R1 Day 400 . Figure 4 shows the variations in feed and effluent $\mathrm{pH}$ with time. Particularly striking is that the effluent $\mathrm{pH}$ was unaffected implying that the system $\mathrm{pH}$ is self-regulatory at $\mathrm{pH}>7.0$ even 


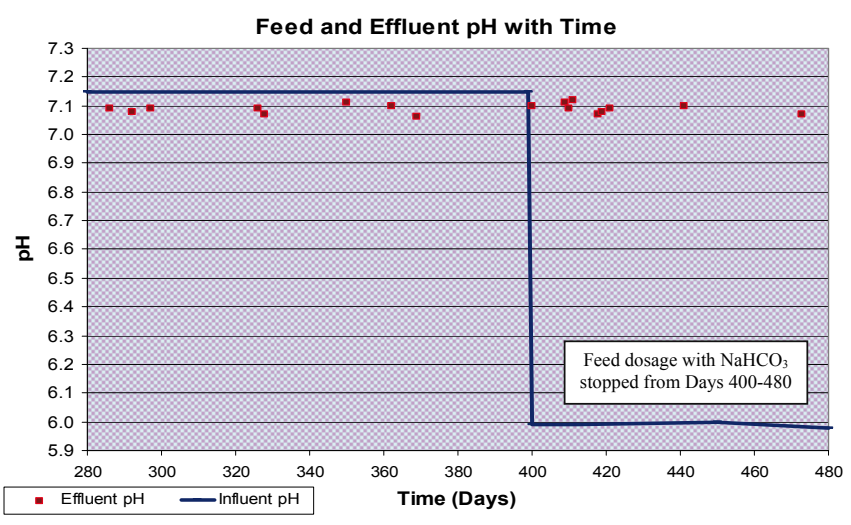

Figure 4

UASB reactor $\mathrm{R} 1$ influent and effluent $\mathrm{pH}$-time profile with $\mathrm{PSS}$ as substrate augmented with $1800 \mathrm{mgSO}_{4}{ }^{2-/ l}$ sulphate

at the high sulphate feed concentration of $1800 \quad \mathrm{mgSO}_{4}{ }^{2-/ \ell}$ due to the high alkalinity generation. Because no $\mathrm{CO}_{2}$ gas was generated (no bubbling was observed in the $\mathrm{FeCl}_{3} \mathrm{H}_{2} \mathrm{~S}$ gas collection bottle, see Part 1, Poinapen et al., 2009a), it seems that all $\mathrm{CO}_{2}$ produced by the breakdown of the PSS biodegradable organics remain in solution as $\mathrm{HCO}_{3}^{-}$. Because the $\mathrm{CO}_{2}$ (or $\mathrm{HCO}_{3}^{-}$) generation may be insufficient to supply the alkalinity required by the sulphate reduction because the organics donate more electrons and protons than supply $\mathrm{C}$ for $\mathrm{HCO}_{3}^{-}$, the sulphide system provides the alkalinity shortfall as dissociated sulphide (HS- ${ }^{-}$wich is proportional to Alk $\mathrm{H}_{2} \mathrm{~S}$; to be presented in Part 5 of Poinapen and Ekama, in preparation).

\section{Comparison of $\mathrm{R} 1\left(35^{\circ} \mathrm{C}\right)$ and $\mathrm{R2}\left(20^{\circ} \mathrm{C}\right)$ (both fed $1500 \mathrm{mgSO}_{4}^{2-/ l)}$}

Since the objective of operating the UASB Reactor R2 was to study the performance of BSR using PSS at ambient temperature (namely $20^{\circ} \mathrm{C}$ ), a comparison between R1 and R2 both fed $1500 \mathrm{mgSO}_{4}^{2-/ \ell}$ was important because most full-scale systems are not likely to be heated to $35^{\circ} \mathrm{C}$. Table 9 lists the performance of the 2 UASB reactors when both were operated at their lowest optimal HRT. The influent characteristics for both R1 and R2 feeds are also listed because this highlights the carbon requirement when operating BSR using PSS at the 2 reactor temperatures. With regard to the effluent quality, both reactors achieved successful BSR and met the set performance criteria (effluent $\mathrm{SO}_{4}{ }^{2-}<250 \mathrm{mgSO}_{4}{ }^{2-} / \ell, \mathrm{VFA}<100 \mathrm{mgHAc} / \ell$ ) with excellent solid liquid separation (Table 9). In terms of the design and operating parameters, such as influent flow $\left(\mathrm{Q}_{\mathrm{i}}\right)$, HRT, BRT, $\mathrm{R}_{\mathrm{s}}$ and bed volume $\left(\mathrm{V}_{\mathrm{b}}\right)$, Reactor $\mathrm{R} 1$ at $35^{\circ} \mathrm{C}$ outperforms $\mathrm{R} 2$ at $20^{\circ} \mathrm{C}$ because the hydrolysis rate of the PSS is strongly decreased by a temperature reduction of $15^{\circ} \mathrm{C}(\sim 30 \%$ reduction in $\mathrm{BPO}$ hydrolysed). The feed PSS COD/ $/ \mathrm{SO}_{4}{ }^{2-}$ ratio of R2 had to be increased to 1.75 to make up for the BPO not hydrolysed. Moreover, R2 had a longer HRT and $\mathrm{V}_{\mathrm{b}}$ in order to increase the BRT and sludge age $\left(\mathrm{R}_{\mathrm{s}}\right)$ thereby improving the utilisation of BPO. Economically these factors favour R1 as it has a more efficient use of BPO ( 90\%) than R2 ( 60\%). However, in practical terms, this advantage might be offset as a UASB reactor would need to be heated to $35^{\circ} \mathrm{C}$ to achieve the R1 performance. A cost-benefit analysis of these 2 reactors' design and operating parameters would be required in order to assess the economics of the 2 systems. The successful

\begin{tabular}{|c|c|c|c|c|c|}
\hline \multicolumn{6}{|c|}{$\begin{array}{c}\text { TABLE } 9 \\
\text { Comparison of } R 1 \text { and } R 2 \text { performance at their } r\end{array}$} \\
\hline \multirow{2}{*}{$\begin{array}{l}\text { Parameters } \\
\text { Measured parameters }\end{array}$} & \multirow[t]{2}{*}{ Units } & \multicolumn{2}{|c|}{$\begin{array}{c}\mathrm{R} 1 \mathrm{at} 35^{\circ} \mathrm{C} \\
\left(1500 \mathrm{mgSO}_{4}{ }^{2-/ \ell}\right)\end{array}$} & \multicolumn{2}{|c|}{$\begin{array}{c}\mathrm{R2} \text { at } 20^{\circ} \mathrm{C} \\
\left(1500 \mathrm{mgSO}_{4}^{2-/ \ell}\right)\end{array}$} \\
\hline & & Influent & Effluent & Influent & Effluent \\
\hline Total COD & $\mathrm{mgCOD} / \ell$ & 1880 & 1165 & 2596 & 1141 \\
\hline $\begin{array}{l}\text { Un-biodegradable particulate COD } \\
\left(\mathrm{f}_{\mathrm{PS}_{\text {up }}}=0.36\right)(\mathrm{UPO})\end{array}$ & $\mathrm{mgCOD} / \ell$ & 677 & - & 935 & - \\
\hline Total soluble COD & $\mathrm{mgCOD} / \ell$ & 236 & $761^{b}$ & 339 & 948 \\
\hline Biodegradable particulate COD (BPO) & $\mathrm{mgCOD} / \ell$ & 967 & - & 1322 & - \\
\hline Un-biodegradable soluble COD (USO) & $\mathrm{mgCOD} / \ell$ & 6 & - & 8 & - \\
\hline SCFA COD & $\mathrm{mgCOD} / \ell$ & 126 & 51 & 169 & 66 \\
\hline Sulphide COD & $\mathrm{mgCOD} / \ell$ & 0 & $627^{b}$ & 0 & 854 \\
\hline Organic soluble COD & $\mathrm{mgCOD} / \ell$ & 230 & $134^{\mathrm{b}}$ & 331 & 96 \\
\hline Sulphate & $\mathrm{mgSO}_{4}^{2-/ \ell}$ & 1500 & 149 & 1500 & 101 \\
\hline Free and saline ammonia (FSA) & $\mathrm{mgN} / \ell$ & 10 & 32 & 10 & 38 \\
\hline $\mathrm{pH}$ & - & $7.20^{\mathrm{a}}$ & 7.15 & 5.94 & 7.21 \\
\hline Sum of $\mathrm{H}_{2} \mathrm{CO}_{3} *$ alkalinity and $\mathrm{Alk} \mathrm{H}_{2} \mathrm{~S}$ & $\mathrm{mg} / \ell$ as $\mathrm{CaCO}_{3}$ & $456^{\mathrm{a}}$ & $1938^{\mathbf{b}}$ & 23 & 1558 \\
\hline $\mathrm{H}_{2} \mathrm{CO}_{3}^{*}$ alkalinity & $\mathrm{mg} / \ell$ as $\mathrm{CaCO}_{3}$ & $456^{\mathrm{a}}$ & $1611^{b}$ & 23 & 1144 \\
\hline Design and operating parameters & & $\begin{array}{r}\mathrm{R} 1 \\
(15001\end{array}$ & $\begin{array}{l}5^{\circ} \mathrm{C} \\
\left.\mathrm{O}_{4}^{2-/ \ell}\right)\end{array}$ & $\begin{array}{r}\mathrm{R} 2 \\
(1500\end{array}$ & \\
\hline Volume of reactor bed after wastage $\left(\mathrm{V}_{\mathrm{b}}\right)$ & $\ell$ & & & & \\
\hline Feed flow rate, $Q_{i}$ & $\ell / \mathrm{d}$ & & & & \\
\hline Hydraulic retention time (HRT) & $\mathrm{h}$ & & & & \\
\hline Sludge age, $\mathrm{R}_{\mathrm{s}}$ & $\mathrm{d}$ & & & & \\
\hline Waste flow rate, $Q_{w}$ & $\ell / \mathrm{d}$ & & & & \\
\hline Upflow velocity, $\mathrm{V}_{\text {up }}$ & $\mathrm{m} / \mathrm{h}$ & & & & \\
\hline
\end{tabular}

a: Alkalinity dosage to R1 feed.

b: Problem in $\mathrm{H}_{2} \mathrm{~S}$ measurement during $\mathrm{R} 1$ first $280 \mathrm{~d}$ of operation 


\begin{tabular}{|c|c|c|c|c|c|c|c|c|c|}
\hline \multicolumn{10}{|c|}{$\begin{array}{c}\text { TABLE } 10 \\
\text { Performance of various bioreactors used for the biological reduction of sulphate-rich wastewaters }\end{array}$} \\
\hline \multirow{2}{*}{$\begin{array}{l}\text { Reactor and process } \\
\text { type }\end{array}$} & \multirow{2}{*}{$\begin{array}{l}\text { Substrate(s) } \\
\text { utilised }\end{array}$} & \multirow{2}{*}{$\begin{array}{l}\text { Tempe- } \\
\text { rature } \\
\left({ }^{\circ} \mathrm{C}\right)\end{array}$} & \multirow{2}{*}{$\begin{array}{l}\text { Hydraulic } \\
\text { retention } \\
\text { time, HRT } \\
\text { (h) }\end{array}$} & \multicolumn{2}{|c|}{$\mathrm{pH}$} & \multicolumn{3}{|c|}{ Sulphate } & \multirow[t]{2}{*}{ Reference(s) } \\
\hline & & & & Feed & Effluent & $\begin{array}{c}\text { Feed } \\
\left(\mathrm{mgSO}_{4}^{2-1 / \ell}\right)\end{array}$ & $\begin{array}{c}\text { Volumetric } \\
\text { reduction } \\
\text { rate } \\
\left(\mathrm{g} / \mathrm{m}^{3} / \mathrm{d}\right)\end{array}$ & $\begin{array}{l}\text { Removal } \\
(\%)\end{array}$ & \\
\hline UASB & PSS & 35 & 13.5 & 7.2 & 7.2 & 1500 & 2792 & 90 & Poinapen et al. (2009a) \\
\hline UASB & PSS & 35 & 18.0 & 6.0 & 7.1 & 1800 & 2423 & 92 & Current paper \\
\hline UASB & PSS & 20 & 20.5 & 5.9 & 7.2 & 1500 & 1737 & 93 & Current paper \\
\hline UASB & Lactate & 35 & 16.0 & 3.0 & 7.7 & 1650 & 1860 & 75 & Kaksonen (2004) \\
\hline $\begin{array}{l}\text { UASB with a } \\
\text { calm zone above } \\
\text { sludge }\end{array}$ & $\begin{array}{l}\text { Ethanol, } \\
\text { nutrients } \\
\text { (+ flocculant) }\end{array}$ & 30 & 4.0 & 3.2 & 7.0 & 1480 & 7010 & 79 & Barnes et al. (1991) \\
\hline FBR & Lactate & 35 & 16.0 & 2.5 & 7.8 & 2290 & 2220 & 65 & Kaksonen (2004) \\
\hline FBR & Ethanol & 35 & 16.0 & 2.5 & 7.7 & 1920 & 2320 & 81 & Kaksonen (2004) \\
\hline FBR & Ethanol & 35 & 6.5 & 3.0 & 7.9 & 2080 & 4290 & 57 & Kaksonen (2004) \\
\hline SBR & Molasses & 31 & 15.0 & - & 7.0 & 2500 & 2712 & 68 & Maree and Strydom (1987) \\
\hline PBR & Molasses & 31 & 20.0 & - & 7.0 & 900 & 525 & 58 & Maree and Strydom (1987) \\
\hline
\end{tabular}

$U A S B=$ upflow anaerobic sludge bed; $F B R=$ fluidised bed reactor; $S B R=$ sludge bed reactor; $P B R=$ packed bed reactor

\begin{tabular}{|c|c|c|c|c|}
\hline \multicolumn{5}{|c|}{$\begin{array}{c}\text { TABLE } 11 \\
\text { Design and operating parameters for BSR UASB system using PSS as carbon and energy source }\end{array}$} \\
\hline \multirow[t]{2}{*}{ Design and operating parameters } & \multirow[t]{2}{*}{ Unit } & \multicolumn{3}{|c|}{$\begin{array}{c}\text { Average values } \\
\end{array}$} \\
\hline & & $\mathrm{R} 1\left(35^{\circ} \mathrm{C}\right)$ & $\mathrm{R} 1\left(35^{\circ} \mathrm{C}\right)$ & $\mathrm{R2}\left(20^{\circ} \mathrm{C}\right)$ \\
\hline Feed PSS COD based on $\mathrm{f}_{\mathrm{PS}^{\prime} \text {, }}$ of 0.36 & $\mathrm{mgCOD} / \ell$ & 1880 & 2584 & 2596 \\
\hline Feed sulphate & $\mathrm{mgSO}_{4}^{2-/ \ell}$ & 1500 & 1800 & 1500 \\
\hline Influent $\mathrm{pH}$ & - & $7.20^{\mathrm{a}}$ & 5.99 & 5.94 \\
\hline Influent flow rate, $\mathrm{Q}_{\mathrm{i}}$ & $\ell / \mathrm{d}$ & 13.6 & 10.4 & 9.2 \\
\hline Organic loading rate, OLR & $\mathrm{g} /\left(\mathrm{m}^{3} \cdot \mathrm{d}\right)$ & 3806 & 3785 & 3224 \\
\hline Sulphate loading rate, SLR & $\mathrm{g} /\left(\mathrm{m}^{3} \cdot \mathrm{d}\right)$ & 3037 & 2637 & 1863 \\
\hline Reactor liquid volume & $\ell$ & 7.8 & 7.8 & 7.8 \\
\hline Reactor bed volume & $\ell$ & 6.7 & 7.1 & 7.4 \\
\hline Sludge recycle ratio (relative to $\mathrm{Q}_{\mathrm{i}}$ ) & - & 0.5 & 0.5 & 0.5 \\
\hline Upflow velocity, $\mathrm{V}_{\text {up }}$ & $\mathrm{m} / \mathrm{h}$ & 0.125 & 0.096 & 0.085 \\
\hline Hydraulic retention time, HRT & $\mathrm{h}$ & 13.8 & 18.0 & 20.4 \\
\hline Sludge aspect ratio (bed height/diameter) & - & 10.5 & 11.2 & 11.6 \\
\hline Bed hydraulic retention time, BRT & $\mathrm{h}$ & 11.9 & 16.4 & 19.3 \\
\hline Sludge retention time (sludge age), $\mathrm{R}_{\mathrm{s}}$ & $\mathrm{d}$ & 18 & 21 & 24 \\
\hline Waste flow rate, $\mathrm{Q}_{\mathrm{w}}$ & $\ell / \mathrm{d}$ & 0.37 & 0.34 & 0.31 \\
\hline Expected sulphate removal rate & $\mathrm{g} /\left(\mathrm{m}^{3} \cdot \mathrm{d}\right)$ & 2735 & 2423 & 1737 \\
\hline Expected sulphate reduction & $\%$ & 90.1 & 91.9 & 93.3 \\
\hline
\end{tabular}

operation of $\mathrm{R} 2$ demonstrates that sulphate reduction using PSS at ambient temperature $\left(20^{\circ} \mathrm{C}\right)$ can be achieved provided a higher feed PSS COD/ $/ \mathrm{SO}_{4}{ }^{2-}$ ratio and/or a longer $\mathrm{R}_{\mathrm{s}}$ is applied.

\section{Comparison of operating parameters and performance with previous studies}

A summary of the performance of the UASB reactors operated in this study along with the performance of various one-stage bioreactors for the treatment of sulphate-rich waters is listed in Table 10. Overall the use of PSS as carbon source (substrate) in UASB systems matches closely (and sometimes exceeds) the performance of systems fed with soluble substrates (namely ethanol, lactate and molasses). This demonstrates the benefits of PSS as a low cost energy source for BSR.

\section{Design and operating parameters}

A summary of the different design and operating parameters applied to the 2 BSR UASB systems of this investigation is listed in Table 11. Two of these parameters are critical and govern the system performance and economics:

- The sludge age $\left(\mathrm{R}_{\mathrm{s}}\right)$ which controls the sludge aspect ratio (bed height/diameter) and hence the reactor bed volume. This in turn will govern the biomass concentration for BPO maximum hydrolysis rate, which is the limiting rate of the system; Ristow et al. (2006) showed that this rate is closely similar to that in methanogenic AD systems treating PSS.

- The HRT controls the reactor volume comprising the bed and liquid phases. A short HRT is always desirable because it reduces the reactor volume. However, too short an HRT 
leads to high upflow velocity and disproportionate bed expansion and sludge wash out. Therefore, the optimum HRT should be established so as to allow sufficient contact time of the sulphate with the sludge bed (biomass) and to optimise the upflow velocity $\left(\mathrm{V}_{\text {up }}\right)$ which governs the bed expansion ratio which in turn dictates the sludge age if a constant bed height is required. Sludge settleability and bed expansion are considered by Poinapen et al. (2009c).

The remaining parameters will then be a consequence of how the sludge age $\left(\mathrm{R}_{\mathrm{s}}\right)$ and HRT are optimised. As far as temperature is concerned, it was found that the feed PSS COD/ $\mathrm{SO}_{4}^{2-}$ ratio had to be increased to 1.75 to cater for incomplete biodegradable particulate organics (BPO) hydrolysis (and consequently low VFA generation) due to the slower hydrolysis/ acidogenesis rate at a temperature of $20^{\circ} \mathrm{C}$ compared with $35^{\circ} \mathrm{C}$. If a high $\%$ of biodegradable organics utilisation is required at the lower temperature, the sludge age of the UASB reactor needs to be increased by increasing the reactor area so that a higher sludge mass is retained in the reactor in relation to that wasted to maintain the bed height, i.e. in effect reducing the volumetric $\mathrm{COD}$ (and $\mathrm{SO}_{4}^{2-}$ ) loading rate.

\section{Conclusions}

The successful operation of the UASB Reactor R2 (fed 1500 $\mathrm{mgSO}_{4}^{2-/ \ell}$ ) at $20^{\circ} \mathrm{C}$ is of significant importance because fullscale systems are not likely to be heated due to the absence of methane gas. Besides the 2 critical parameters ( $\mathrm{R}_{\mathrm{s}}$ and HRT) which are both longer at $20^{\circ} \mathrm{C}$ than at $35^{\circ} \mathrm{C}$, the other important parameter in the operation of BSR systems using PSS is the feed PSS COD/SO ${ }_{4}^{2-}$ ratio. By decreasing the temperature from $35^{\circ} \mathrm{C}$ to $20^{\circ} \mathrm{C}$, the PSS biodegradable particulate organics (BPO) hydrolysis rate is decreased and less than $70 \%$ of the BPO is hydrolysed thereby generating less VFA for BSR. Increasing the PSS COD/ $\mathrm{SO}_{4}{ }^{2-}$ from 1.25 (applied to R1) to 1.75 (applied to R2) increased the BPO concentration hydrolysed to meet the VFA demand for sulphate reduction. Alternatively, increasing the sludge age of the system by reducing the volumetric COD and sulphate load would increase the \% BPO hydrolysed while maintaining the feed PSS COD/SO ${ }_{4}{ }^{2-}$ at 1.25 .

UASB R1 was operated at an increased influent sulphate concentration $\left(1800 \mathrm{mgSO}_{4}^{2-/ \ell}\right)$ to investigate the inhibition effect by un-dissociated hydrogen sulphide generated from the reduction of this sulphate concentration level. It was found that high sulphate reduction $(\sim 92 \%)$ was achieved even at the relatively low HRT of $18.5 \mathrm{~h}$. This observation is important in calibrating the value of the acetotrophic (acetate using) SRB inhibition constant $\left(\mathrm{K}_{\mathrm{I}}\right)$ in the dynamic kinetic simulation model (UCTADM1-BSR) developed in Part 6 of this series, which is currently in preparation by Poinapen and Ekama.

\section{Acknowledgements}

This research was supported financially by the Water Research Commission, the National Research Foundation and the University of Cape Town and is published with their permission.

\section{References}

BARNES LJ, JANSSEN FJ, SHERREN J, VERSTEEGH JH, KOCH RO and SCHEEREN PJH (1991) A new process for the microbial removal of sulphate and heavy metals from contaminated waters extracted by a geohydrological control system. Trans. Inst. Chem. Eng. 69 184-186.

KAKSONEN HA (2004) The Performance, Kinetics and Microbiology of Sulphidogenic Fluidised-Bed Reactors Treating Acidic Metaland Sulphate-Containing Wastewater. Ph.D. dissertation. Institute of Environmental Engineering and Biotechnology, Tampere University of Technology, Finland.

KALYUZHNYI SV, DE LEON FRAGOSO C and RODRIGUES MARITNEZ J (1997) Biological sulphate reduction in a UASB reactor fed with ethanol as electron donor. Mikrobiologiya $\mathbf{6 6}$ 687-693.

KONISHI Y, YOSHIDA N and ASAI S (1996) Desorption of hydrogen sulphide during batch growth of the sulphate-reducing bacterium Desulfovibrio desulphuricans. Biotechnol. Prog. 12 322-330.

MAILLACHERUVU KY, PARKIN GF, PENG CY, KUO W, OONGE ZI and LEBDUSCHKA V (1993) Sulphide toxicity in anaerobic systems fed sulphate and various organics. Water Environ. Res. 65 100-109.

MAREE JP and STRYDOM WW (1987) Biological sulphate removal from industrial effluents in an upflow packed bed reactor. Water Res. 21 141-146.

O'FLAHERTY V, MAHONY T, O'KENNEDY R and COLLERAN $\mathrm{M}$ (1998) Effect of $\mathrm{pH}$ on growth kinetics and sulphide toxicity thresholds of a range of methanogenic, syntrophic and sulphatereducing bacteria. Proc. Biochem. 33 1-15.

POINAPEN J, EKAMA GA and WENTZEL MC (2009a) Biological sulphate reduction with primary sewage sludge in an upflow anaerobic sludge bed (UASB) reactor - Part 1: Feasibility study. Water SA 35 (5) 525-534.

POINAPEN J, EKAMA GA and WENTZEL MC (2009b) Biological sulphate reduction with primary sewage sludge in an upflow anaerobic sludge bed (UASB) reactor - Part 2: Modification of simple wet chemistry analytical procedures to achieve COD and $\mathrm{S}$ mass balances. Water SA 35 (5) 535-542.

POINAPEN J, EKAMA GA and WENTZEL MC (2009c) Biological sulphate reduction with primary sewage sludge in an upflow anaerobic sludge bed (UASB) reactor - Part 4: Bed settling characteristics. Water $S A 35$ (5) 553-558.

REIS MAM, ALMEIDA JS, LEMOS PC and CARRONDO MJT (1992) Effect of hydrogen sulphide on growth of sulphate reducing bacteria. Biotechnol. Bioeng. 40 593-600.

RISTOW NE, SÖTEMANN SW, WENTZEL MC, LOEWENTHAL RE and EKAMA GA (2006) The effects of hydraulic retention time and feed COD concentration on the hydrolysis rate of primary sewage sludge. Water Sci. Technol. 54 (5) 91-100. 